\title{
Physicochemical, Phytochemical and Pharmacognostic Evaluation of a Halophytic Plant, Trianthema portulacastrum L.
}

\author{
Pande Jyoti, Kanakiya Ankita, Padalia Hemali and Chanda Sumitra* \\ Phytochemical, Pharmacological and Microbiological laboratory, Department of Biosciences \\ (UGC-CAS), Saurashtra University, Rajkot-360005, India \\ *Corresponding author
}

\begin{tabular}{|c|}
\hline Keywords \\
\hline $\begin{array}{l}\text { Trianthema } \\
\text { portulacastrum, } \\
\text { Aizoaceae, Halophyte, } \\
\text { Phytochemical analysis, } \\
\text { Pharmacognostic studies, } \\
\text { Powder microscopy }\end{array}$ \\
\hline Article Info \\
\hline $\begin{array}{l}\text { Accepted: } \\
12 \text { April } 2018 \\
\text { Available Online: } \\
10 \text { May } 2018\end{array}$ \\
\hline
\end{tabular}

\section{A B S T R A C T}

Trianthema portulacastrum L. belongs to the family Aizoaceae. It is an important medicinal halophyte, traditionally used to cure many diseases and disorders. It order to ensure authenticity and maintain the therapeutic efficacy of this plant, evaluation of certain quality control parameters for the standardization of this plant was attempted. To achieve this, physicochemical, phytochemical and pharmacognostic studies of this plant was done. For phytochemical analysis, phenols, flavonoids, cardiac glycosides, tannins, steroids, saponins, triterpenes, coumarins, phlobatanins, etc. were evaluated. For physicochemical analysis, loss on drying, total ash, water soluble, acid insoluble, sulphated, nitrated and carbonated ash were determined. The extractive values in different polar and non-polar solvents were measured. Finally macroscopic, microscopic and powder study of leaf and stem was done. All the standard methods were followed for different estimations. The crude powder of $T$. portulacastrum was rich in coumarins; while its solvent extracts toluene and ethylacetate were rich in steroids. In physicochemical analysis loss on drying was $9.5 \%$. The ash values ranged from $0.83 \%$ to $11.83 \%$. The extractive values of organic solvents ranged from $0.52 \%$ to $8.64 \%$ and water soluble extractive value was $17.74 \%$. Maximum extractive value was in methanol and water indicating presence of more polar compounds than nonpolar compounds. The macroscopic, microscopic and powder characteristics of leaf and stem was measured. The parameters evaluated in this study will safeguard the authenticity and efficacy of crude drug and also distinguish the drug from its adulterants. The parameters enlisted in this study will be useful and helpful in setting diagnostic indices for identification and preparation of monograph of this plant

\section{Introduction}

The practice of traditional medicine is based on hundreds of years of belief and observations and analysis, which help in the development of modern medicine. Today interest in herbal drugs is increasing primarily based upon the idea that herbal medicines are safe, inexpensive and have less adverse effects. Each plant drug possesses unique properties in terms of its botany, chemical constituents and therapeutic potency. In folkloric medicine, plants are used for curing various diseases mainly based on popular belief passed on from generation to generation. For e.g. Costus pictus, known as 'insulin plant', a member of Costaceae family is used as a munching dietary supplement for 
the treatment of diabetes in Southern India (Jayasri et al., 2008). Enicostema littorale is another herb of family Gentianaceae used for hypoglycemic activity found in many parts of India such as Gujarat and Maharashtra (Maroo et al., 2003). The only shortcoming of traditional medicine is there are no stringent quality control parameters; in other words, there are no standardization parameters and hence they are prone to adulteration and substitution and puts doubt on their efficacy. Their chance of getting adulterated is directly proportional to their efficacy and availability. So it is important to study pharmacognostic characters of each medicinal plant to differentiate the unadulterated plant sample.

Among the medicinal plants, halophytic plants are very significant. Halophytic vegetation dominates the tidal marsh ecosystems. Plants develop specific anatomical, morphological, and physiological characteristics enabling them to perform their vital functions in the presence of large concentrations of harmful salts. The ability of some of the halophytes to resist high salt conditions is because of two main mechanisms either they exclude the salt well in leaves (salt exclusion) or compartmentalize. Most of the medicinal halophyte plants are herbs and forbs and are perennial and their biological types were therophyte and chameophyte (Priyashree et al., 2010).

Trianthema portulacastrum L. belongs to the family Aizoaceae, commonly known as noxious weed, horse purslane, hogweed, itcit or santha. It is a prostrate, glabrous, succulent herb found almost throughout India in cultivated and wastelands. The plant is bitter, alexiteric, analgesic, stomachic, laxative. It has been reported for some traditional use as anthelmintic, vermifuge and antirhematitis (Shastri, 1952) and serves as alterative cure for bronchitis, heart disease, blood anaemia, inflammation, and piles, ascites. The root applied to the eye cures corneal ulcers, itching, dimness of sight and night blindness (Kirtikar and Basu, 1933). It is also used as vegetable in various parts of world due to its high nutritional value. Two forms are reported of this plant, a red coloured form in which the stem, leaf margin and flowers are red; and a green coloured form which has a green stem and white flowers. The leaves possess diuretic properties (Balamurugan et al., 2009). The plant shows hepatoprotective (Kumar et al., 2004) and antioxidant activity (Sunder et al., 2010).

In the present study, an attempt has been done to lay down some standardization parameters for Trianthema portulacastrum leaf and stem. Hence the objectives of the study were to evaluate organoleptic features, macroscopic and microscopic evaluation of $T$. portulacastrum leaf and stem. The whole plant dry powder was evaluated for its phytochemical, physicochemical and fluorescence analysis.

\section{Materials and Methods}

\section{Plant collection}

The halophytic plant Trianthema portulacastrum L. was collected in August, 2017 from Porbandar, Gujarat, India. The plant was washed thoroughly was tap water, shade dried and homogenized to fine powder and stored in closed container for further studies.

\section{Pharmacognostic study}

\section{Macroscopic study}

The macroscopic studies were carried out using organoleptic evaluation method. The arrangement, size, shape, base, texture, margin, apex, veination, colour, odour, taste of leaves and stem were observed. Macroscopic 
and microscopic characters were studied as described in quality control method (Khandelwal, 2008). Photographs at different magnifications were taken by using digital camera.

\section{Microscopic study}

Microscopic study was carried out by preparing thin sections of stem and leaf. The thin sections were further washed with water, stained with safranin, fast green and mounted in glycerine for observation and confirm its lignifications (10x, 40x) (Tyler et al., 1977).

\section{Powder microscopy}

The powder microscopy of the whole plant powder was studied using standard procedure by capturing the images of different fragments of tissues and diagnostic characteristic features were recorded (Tyler et al., 1977).

\section{Physicochemical analysis}

The physicochemical parameters like loss on drying, total ash, acid-insoluble ash, watersoluble ash, sulphated ash and extractive values were determined as per WHO guidelines (WHO, 1998).

The solvents used were petroleum ether (PE), toluene (TO), ethyl acetate (EA), methanol (ME) and water (AQ). The details of the procedure followed are as described earlier (Pande and Chanda, 2017).

\section{Phytochemical analysis}

The qualitative phytochemical analysis of crude powder and different solvent extracts of whole plant powder and different solvent extracts of Trianthema portulacastrum was carried out to identify different phytoconstitutents (Harbone, 1998). The phytoconstituents analysed were alkaloids, flavonoids, phenols, saponins, tannins, cardiac glycosides, steroids, phlobatanins, triterpenes, anthocyanins, etc. The presence of specific phytochemicals indicated is indicated with $(+)$ sign and the absence of phytochemicals is indicated with (-) sign. The procedure followed for different phytochemical analysis is given Table 1.

\section{Fluorescence analysis}

Fluorescence study of different plants powder was performed as per Chase and Pratt (1949). A small quantity of the plants powder was placed on a grease free clean microscopic slide and 1-2 drops of freshly prepared reagent solution were added, mixed by gentle tilting of the slide and waited for a few minutes. Then the slide was placed inside the UV chamber and observed in visible light, short (254 nm) and long $(365 \mathrm{~nm})$ ultra violet radiations. The colours observed by application of different reagents in different radiations were recorded.

\section{Results and Discussion}

\section{Organoleptic and macroscopic characteristic of Trianthema portulacastrum L.}

T. portulacastrum is a prostrate, sub-succulent herb and facultative halophyte. The organoleptic and macroscopic characteristics of the plant are given in Table 2 and Figure 1.

\section{Leaves}

The leaf was simple, green in colour, phyllotaxy was obliquely opposite, shape was obovate, margin was entire, apex was apicular, base was asymmetrical, veination was reticulate, petiole was long. Outer surface was smooth and fleshy. The odour was characteristic and taste was bitter. The average size of leaf was $5-6 \mathrm{~cm}$ length and $2-4 \mathrm{~cm}$ wide (Fig. 1a and Table 2). 


\section{Stem}

The stem was light pink in colour, branched, woody, prostrate. Outer surface was glabrous. The average size of the stem was $10 \mathrm{~cm}$ long and $0.2-0.5 \mathrm{~cm}$ thick (Fig. $1 \mathrm{~b}$ and Table 2).

\section{Microscopic characteristic}

\section{Petiole}

The transverse section of $T$. portulacastrum petiole is shown in Figure 2. The petiole was bean shaped. The single layered upper and lower epidermis was surrounded by thin cuticle layer (Fig. 2a).

The epidermis was covered with unicellular and multicellular, 2-3 celled trichomes. Ground tissue was parenchymatous, vascular bundles were three in numbers, the size of the vascular bundles varied from centre to leaf margin i.e. large too small. They were centripetal arranged i.e. xylem surrounded by the phloem (Fig. 2b).

\section{Leaf}

The transverse section of $T$. portulacastrum leaf is shown in Figure 2. The leaf lamina was dorsiventral in nature. The upper epidermis and lower epidermis were single layered. The palisade tissue was single layered on the upper surface, it was covered with thick cuticle (Fig. 2c). The lower surface of leaf showed unicellular trichomes. The mesophyll was small, consisted of 4-7 layered. T.S. passing through the mid rib region showed vascular bundles towards the ventral surface and it was surrounded by palisade tissues (Fig. 2d). Centrally located conjoint collateral vascular bundles were surrounded by spongy parenchymatous cells. The xylem was surrounded by phloem (Fig. 2e). The paracytic stomata were present in lower epidermis (Fig. 2f).

\section{Stem}

The transverse section of $T$. portulacastrum stem is shown in Figure 3. The epidermis was single layered thick walled, narrow, small and it was surrounded by thick cuticle layer (Fig. 3a). The unicellular and multicellular trichomes were present on the outer surface of the epidermis. The cortex region consisted of 6-8 layers (Fig. 3b). The vascular bundles were present in the pith region. The plant showed secondary growth, phloem was present below the xylem (Fig. 3c).

The vascular bundles were surrounded by polygonal parenchymatous cells, vascular bundles were conjoint, collateral, close type, arranged in a ring form (Fig. 3d). The vascular bundles were eight to ten in number without cambium ring, pith was made up of welldeveloped parenchymatous tissue (Fig. 3e). The xylem was well developed and consisted of vessels, fibres, metaxylem and xylem parenchyma. Phloem consisted of sieve tubes, companion cells and phloem parenchyma (Fig. $3 f)$.

\section{Powder microscopy of the plant}

The crude powder of the $T$. portulacastrum plant was green in colour, taste was bitter and odour was characteristic. The powder microscopic characteristics are shown in Figure 4. The specific characteristics of powder determined by microscopic investigation showed unicellular trichomes, multicellular trichomes, spiral vessels, annual vessels, bordered pitted vessels, pitted vessels, paracytic stomata, sclerenchymatous cells, etc.

\section{Physicochemical analysis}

The physicochemical analysis of $T$. portulacastrum plant is given in Figure 5 and 6 . The loss on drying of dry powder of plant was $9.5 \%$. 
Table.1 Phytochemical analysis

\begin{tabular}{|c|c|c|c|}
\hline No. & Phytochemicals & Test & Observation \\
\hline 1 & Alkaloids & $\begin{array}{l}\text { Add crude powder and solvent extracts } \\
\text { to } 2 \mathrm{~N} \mathrm{HCl} \text { and mixture was filtrated. } \\
\text { 1) The filtrate was treated with } \\
\text { few drops of Dragondroff's reagent }\end{array}$ & $\begin{array}{l}\text { Formation of orange precipitate } \\
\text { indicated the presence of } \\
\text { alkaloids. }\end{array}$ \\
\hline & & $\begin{array}{l}\text { 2) The filtrate was treated with } \\
\text { few drops of Mayer's reagent. } \\
\text { 3) The filtrate was treated with } \\
\text { few drops of Wagner's reagent }\end{array}$ & $\begin{array}{l}\text { Formation of Cream precipitate } \\
\text { indicated the presence of } \\
\text { alkaloids. } \\
\text { Formation of brown precipitate } \\
\text { indicated the presence of } \\
\text { alkaloids. }\end{array}$ \\
\hline 2 & Phenols & $\begin{array}{l}\text { The crude powder and solvent extracts } \\
\text { was dissolved in distilled water. It was } \\
\text { filtered the filtrate was treated with a } \\
\text { few drops of } 5 \% \mathrm{FeCl}_{3} \text { solution }\end{array}$ & $\begin{array}{l}\text { Formation of deep blue colour } \\
\text { indicated the presence of } \\
\text { phenols }\end{array}$ \\
\hline 3 & Flavonoids & $\begin{array}{l}\text { The crude powder and solvent extracts } \\
\text { was dissolved in distilled water. It was } \\
\text { filtered the filtrate was treated with a } \\
\text { few drops of diluted } \mathrm{NaOH} \text {, again add } \\
\text { few drops of diluted } \mathrm{HCl}\end{array}$ & $\begin{array}{l}\text { Formation of yellow orange } \\
\text { colour to colourless indicated } \\
\text { the presence of flavonoids }\end{array}$ \\
\hline 4 & $\begin{array}{l}\text { Saponins } \\
\text { (Frothing test) }\end{array}$ & $\begin{array}{l}\text { The crude powder and solvent extracts } \\
\text { of different plants was vigorously } \\
\text { shaken with distilled water and } \\
\text { allowed to stand for } 10 \text { min. }\end{array}$ & $\begin{array}{l}\text { Stable formation of froth for } 1 \\
\text { min indicated presence of } \\
\text { saponins }\end{array}$ \\
\hline 5 & $\begin{array}{l}\text { Tannins } \\
\left(\mathrm{FeCl}_{3} \text { test }\right)\end{array}$ & $\begin{array}{l}\text { The crude powder and solvent extracts } \\
\text { of different plants was dissolved in } \\
\text { distilled water. It was filtered and the } \\
\text { filtrate was treated with alcoholic } \\
\text { ferric chloride }\left(\mathrm{FeCl}_{3}\right) \text { reagent }\end{array}$ & $\begin{array}{l}\text { Formation of blue colour } \\
\text { indicated the presence of } \\
\text { tannins }\end{array}$ \\
\hline$\overline{6}$ & $\begin{array}{l}\text { Steroids } \\
\text { (Liebennann - } \\
\text { Burchard test) }\end{array}$ & $\begin{array}{l}\text { The crude powder and solvent extracts } \\
\text { of different plants was dissolved in } \\
\text { chloroform. It was filtered and the } \\
\text { filtered chloroform extract was treated } \\
\text { with acetic anhydride and a few drops } \\
\text { of concentrated } \mathrm{H}_{2} \mathrm{SO}_{4}\end{array}$ & $\begin{array}{l}\text { Formation of blue green ring } \\
\text { indicated the presence of } \\
\text { steroids }\end{array}$ \\
\hline 7 & Phlobatanins & $\begin{array}{l}\text { The crude powder and solvent extracts } \\
\text { of different plants was boiled with } 1 \% \\
\text { aqueous } \mathrm{HCl}\end{array}$ & $\begin{array}{l}\text { Formation of red precipitate } \\
\text { indicated the presence of } \\
\text { phlobatannins }\end{array}$ \\
\hline 8 & Anthocyanins & $\begin{array}{l}\text { The crude powder and solvent extracts } \\
\text { of different plants was dissolved in } \\
\text { methanol. It was filtered and the } \\
\text { filtered methanolic extract was treated } \\
\text { with } 2.0 \mathrm{ml} \mathrm{NaOH}(1 \mathrm{~N})\end{array}$ & $\begin{array}{l}\text { The colour of the solution } \\
\text { changed to blue indicated the } \\
\text { presence of anthocyanins }\end{array}$ \\
\hline 9 & Triterpenes & $\begin{array}{l}\text { The crude powder and solvent extracts } \\
\text { of different plants was dissolved in } \\
\text { chloroform. It was filtered and the }\end{array}$ & $\begin{array}{l}\text { Formation of reddish brown } \\
\text { ring indicated the presence of } \\
\text { triterpens }\end{array}$ \\
\hline
\end{tabular}




\begin{tabular}{|c|c|c|c|}
\hline & & $\begin{array}{l}\text { filtered chloroform extract was treated } \\
\text { with concentrated } \mathrm{H}_{2} \mathrm{SO}_{4}\end{array}$ & \\
\hline 10 & $\begin{array}{l}\text { Cardiac Glycosides } \\
\text { (Keller - Kiliani test) }\end{array}$ & $\begin{array}{l}\text { The crude powder and solvent extracts } \\
\text { of different plants was dissolved in } \\
\text { distilled water. It was filtered and the } \\
\text { filtered aqueous extract was treated } \\
\text { with } 1.0 \mathrm{ml} \text { mixture of } 5 \% \mathrm{FeCl}_{3} \text { and } \\
\text { glacial acetic acid }(1.99 \mathrm{~V} / \mathrm{V}) \text {. To this } \\
\text { solution, few drops of concentrated } \\
\mathrm{H}_{2} \mathrm{SO}_{4} \text { was added }\end{array}$ & $\begin{array}{l}\text { Appearance of greenish blue } \\
\text { colour within few minutes } \\
\text { indicated the presence of } \\
\text { cardiac glycosides }\end{array}$ \\
\hline 11 & Coumarins & $\begin{array}{l}\text { The crude powder and solvent extracts } \\
\text { of different plants was dissolved in } \\
\text { distilled water. It was filtered and the } \\
\text { filtered aqueous extract was treated } \\
\text { with } 10 \% \mathrm{NaOH}\end{array}$ & $\begin{array}{l}\text { Formation of yellow colour of } \\
\text { the solution indicated the } \\
\text { presence of coumarins. }\end{array}$ \\
\hline 12 & Leucoanthocyanins & $\begin{array}{l}\text { The crude powder and solvent extracts } \\
\text { of different plants was dissolved in } \\
\text { distilled water. It was filtered and the } \\
\text { filtered aqueous extract was treated } \\
\text { with isoamyl alcohol in equal } \\
\text { proportion. }\end{array}$ & $\begin{array}{l}\text { Appearance of red colour in } \\
\text { upper layer indicated the } \\
\text { presence of leucoanthocyanins }\end{array}$ \\
\hline 13 & Quinones & $\begin{array}{l}\text { The crude powder and solvent extracts } \\
\text { of different plants was dissolved in } \\
\text { methanol. It was filtered and the } \\
\text { filtered methanolic extract was treated } \\
\text { with } \mathrm{HCl}\end{array}$ & $\begin{array}{l}\text { Formation of yellow } \\
\text { precipitation indicated the } \\
\text { presence of quinones }\end{array}$ \\
\hline
\end{tabular}

Fig.1 Macroscopic study of Trianthema portulacastrum L.

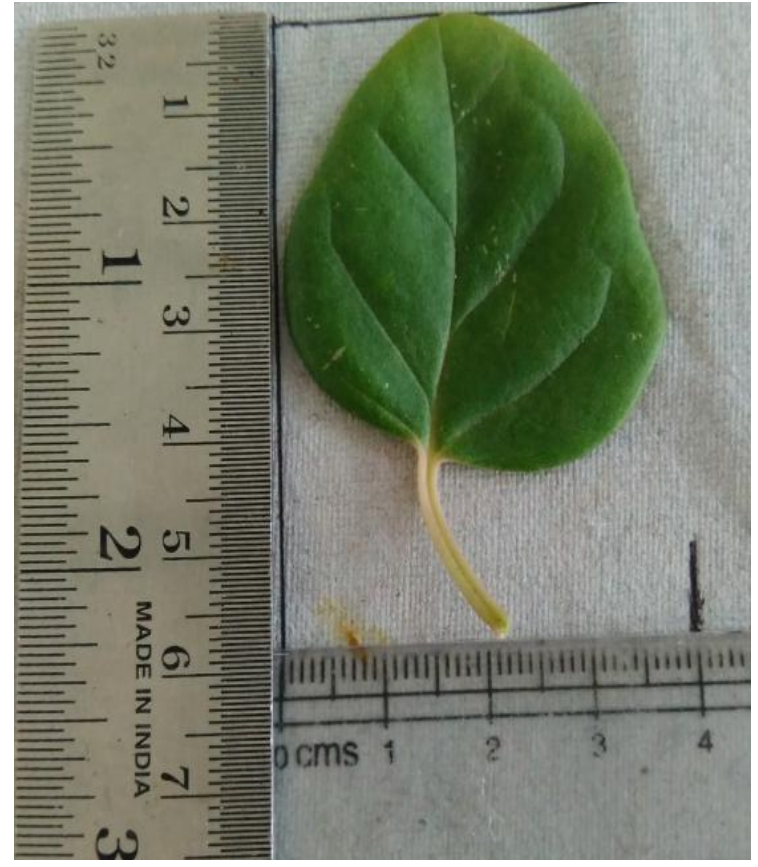

a) Leaf with petiole

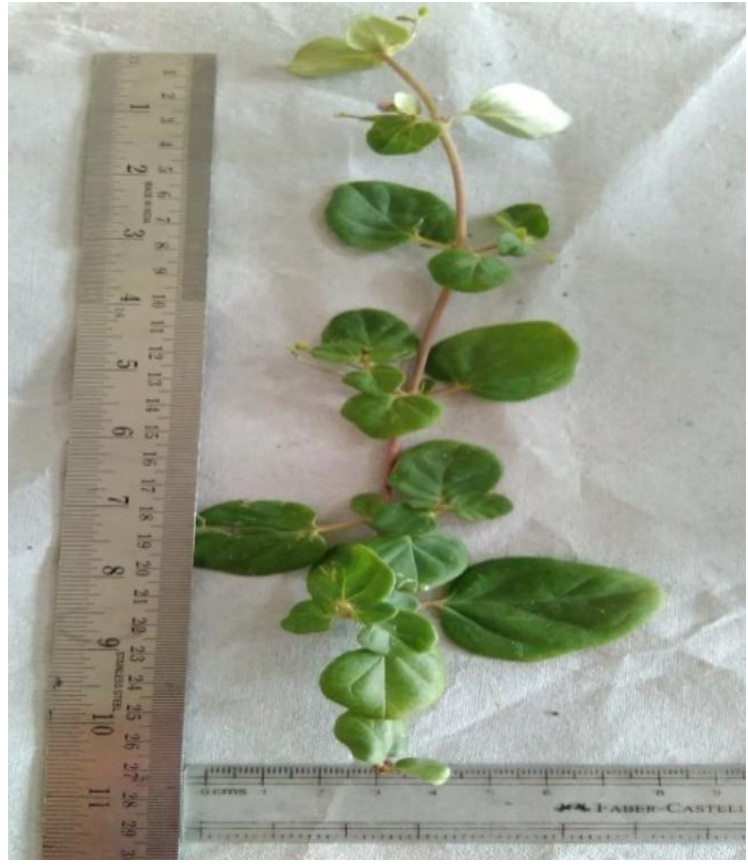

b) Stem 
Fig.2 Microscopic study of leaf of T. portulacastrum

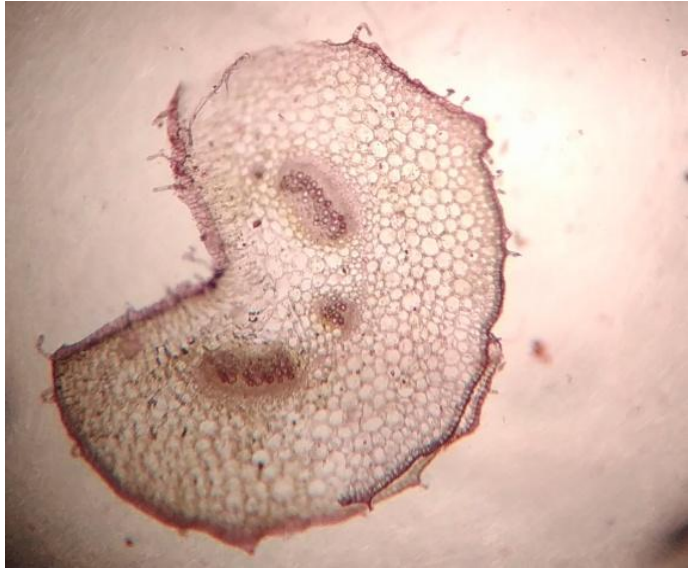

a) T.S. of petiole

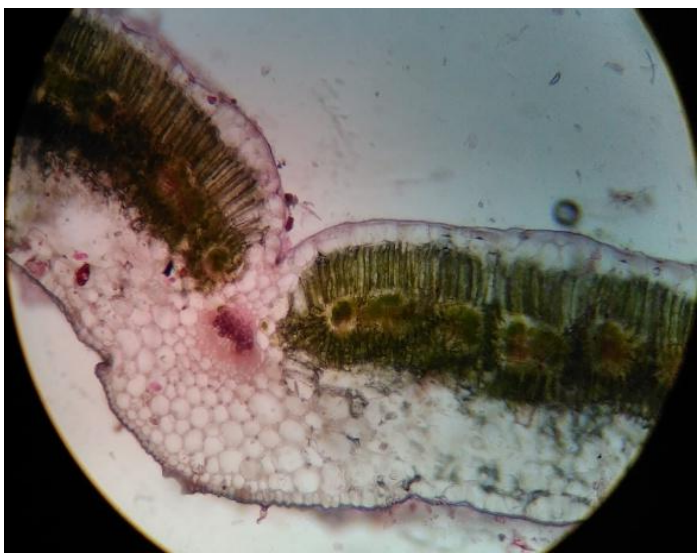

c) T.S. of leaf with epidermis

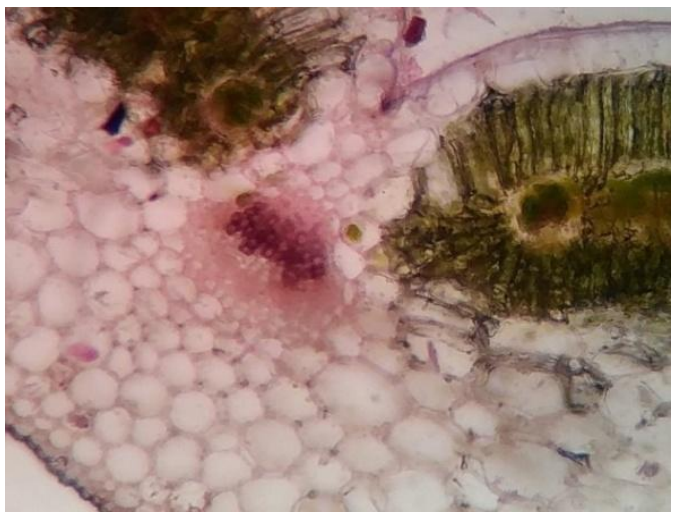

e) T.S. of leaf with vascular bundles

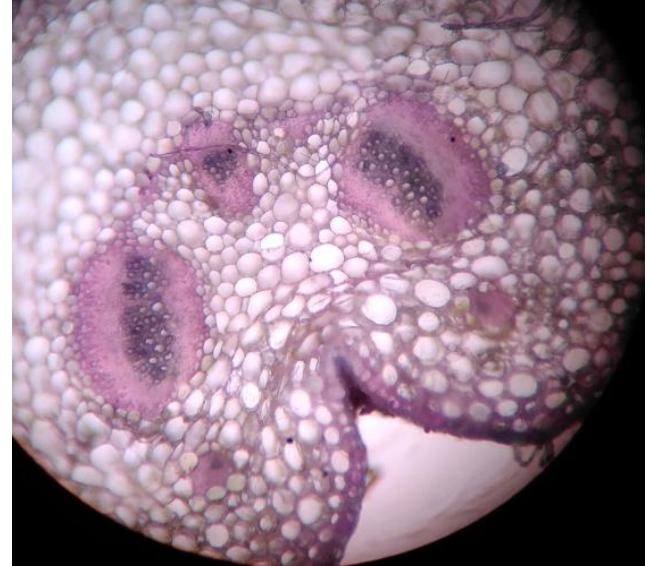

b) T.S of petiole with vascular bundles

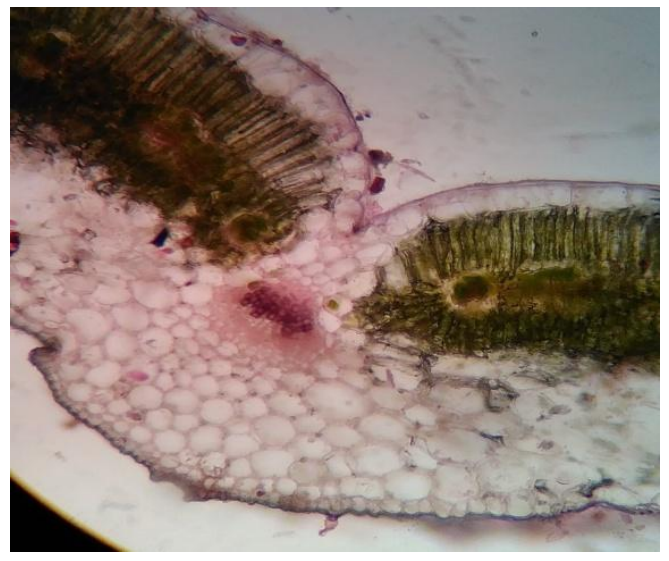

d) T.S. of leaf with palisade cells

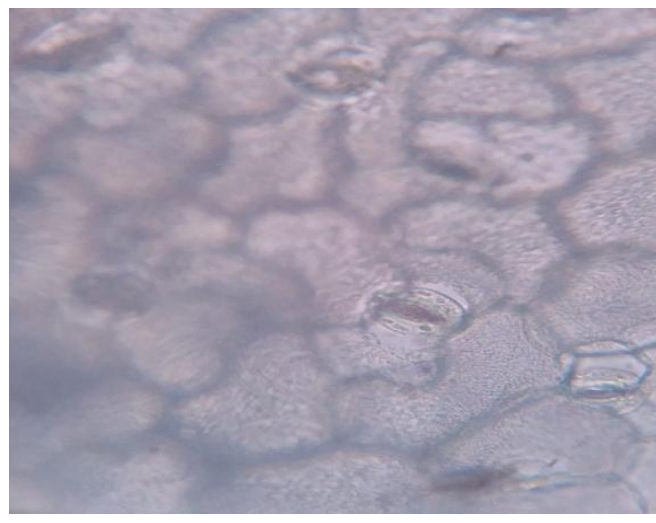

f) Paracytic stomata 
Fig.3 Microscopic study of stem of T. portulacastrum

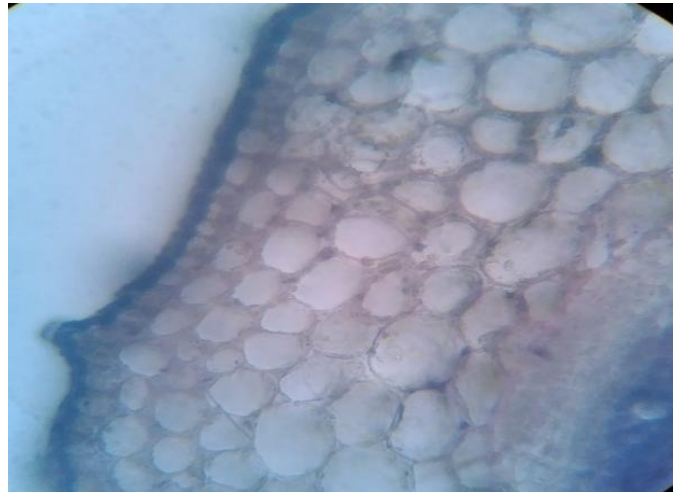

a) T.S. of stem with epidermis

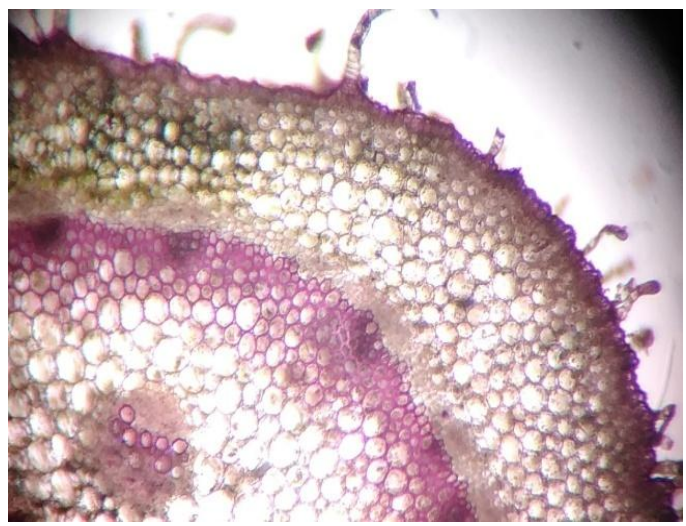

c) T.S. of stem with trichomes

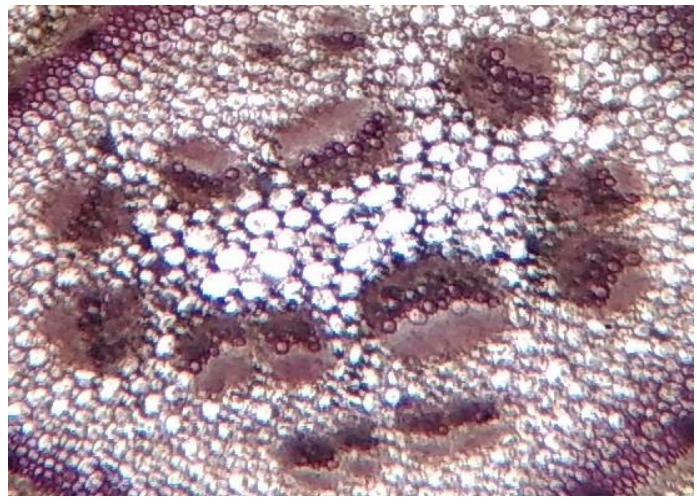

e) T.S. of stem with vascular bundles

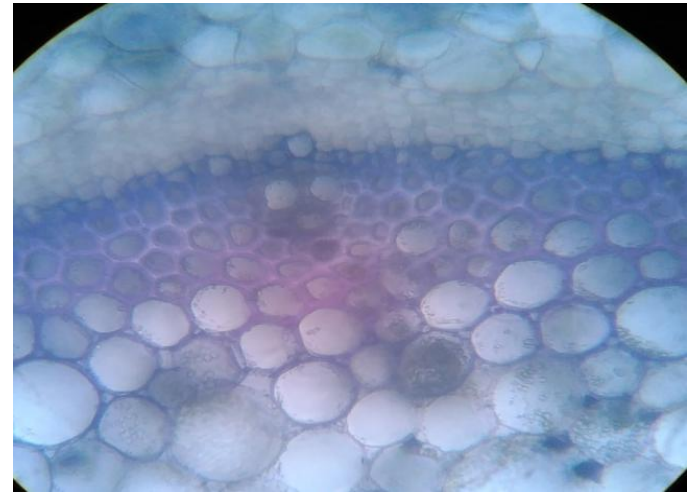

b) T.S. of stem with annual ring

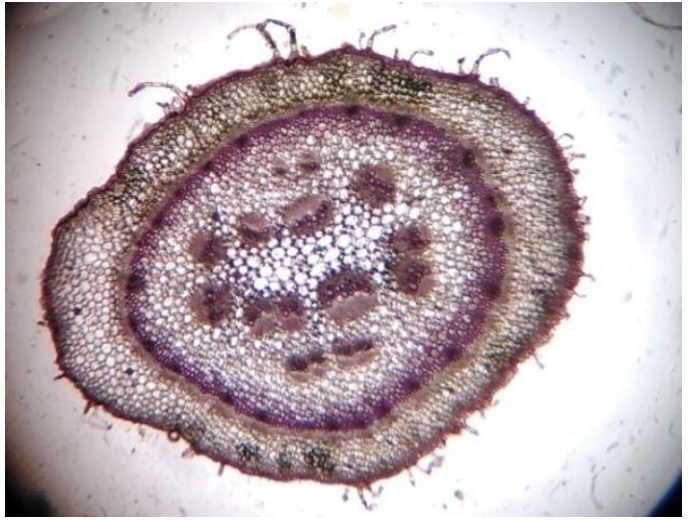

d) T.S. of whole stem

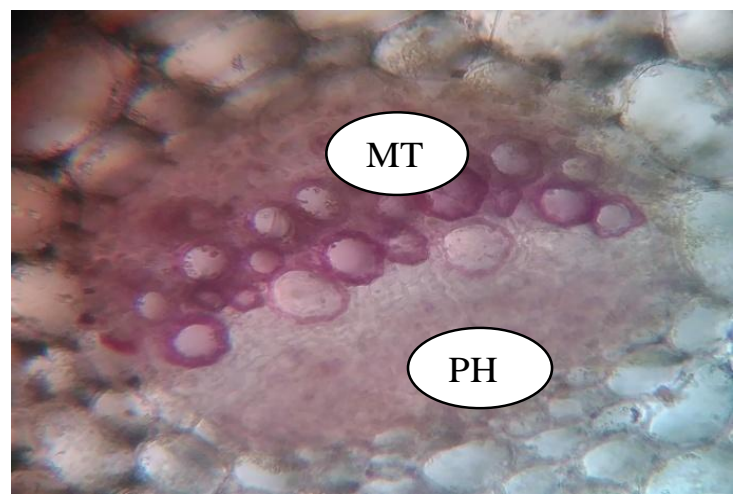

f) T.S. of stem with metaxylem and phloem 
Fig.4 Powder study of $T$. portulacastrum

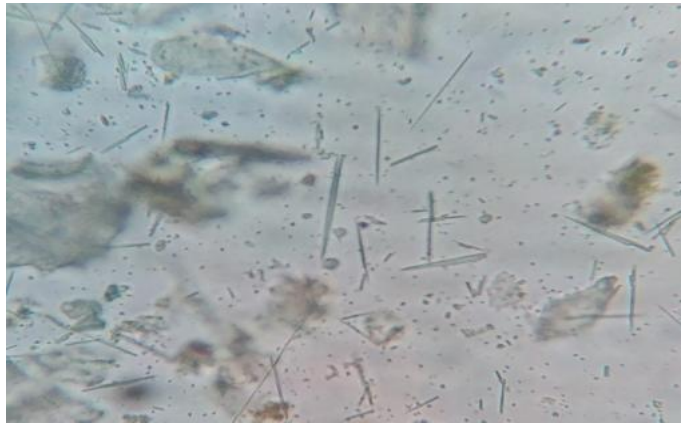

a) Unicellular trichomes

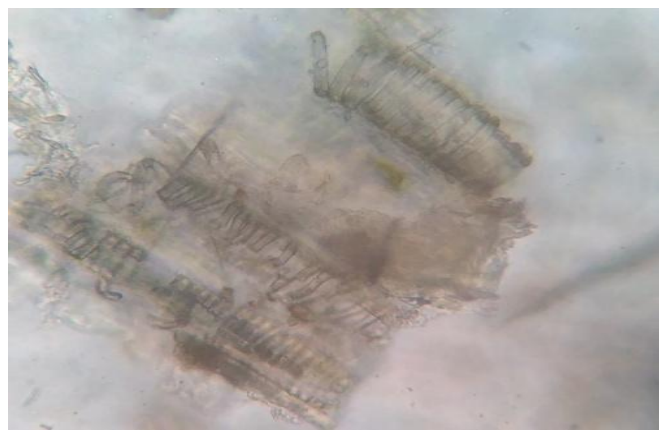

c) Spiral vessels

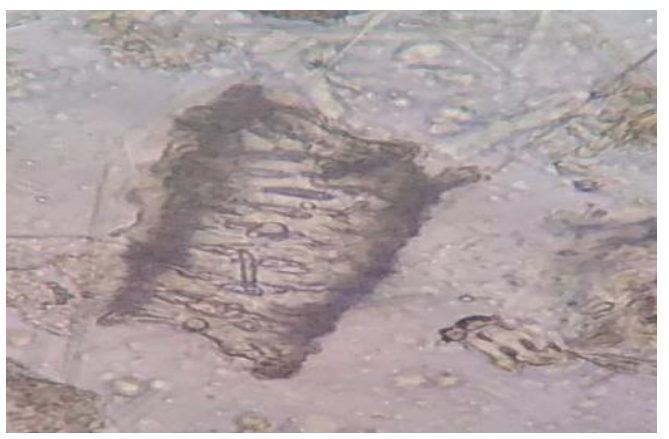

e) Bordered pitted vessels

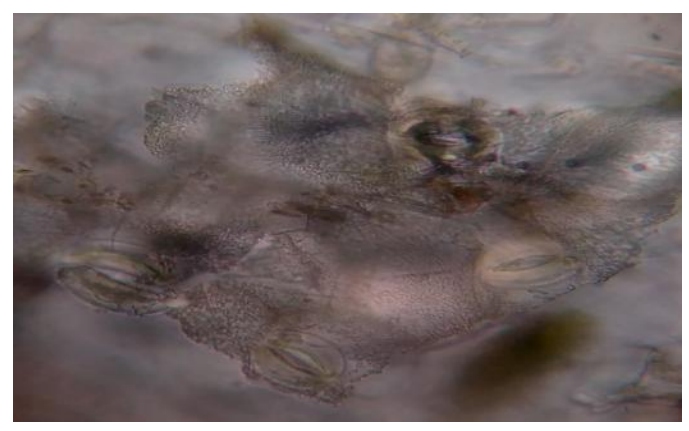

g) Paracytic stomata

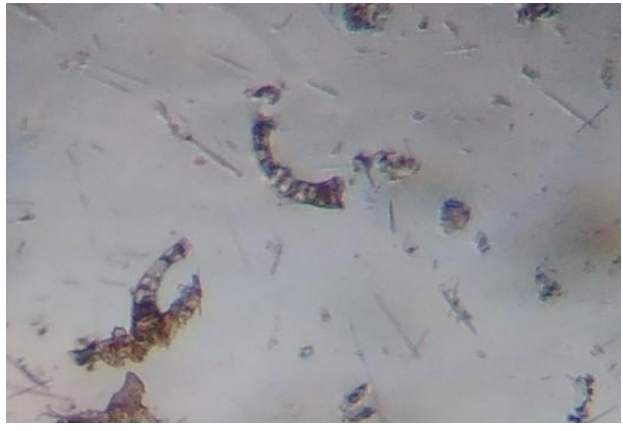

b) Multicellular trichomes

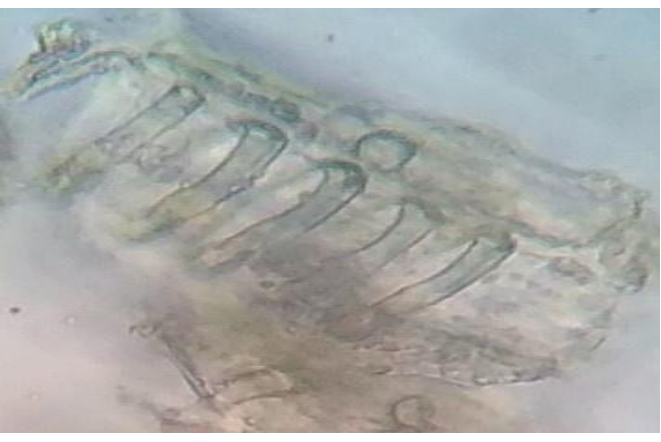

d) Annular vessels

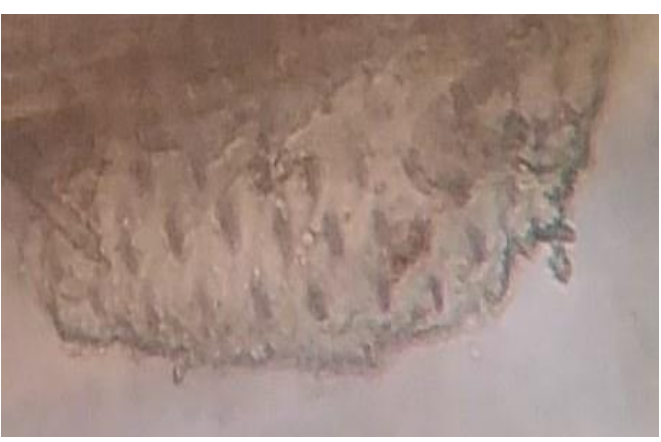

f) Pitted vessels

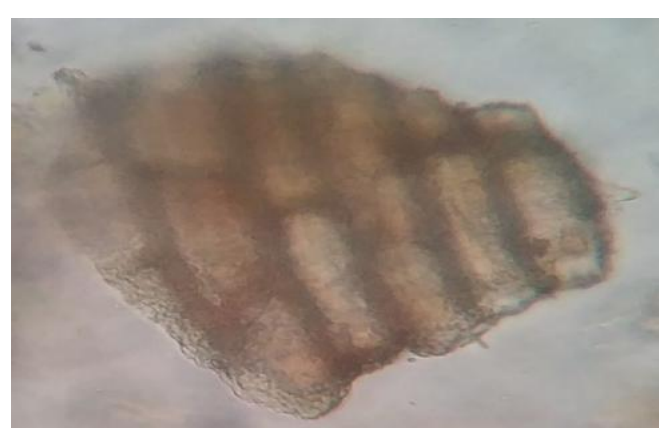

h) Sclerenchymatous cells 
Fig.5 Ash values of crude powder of T. portulacastrum

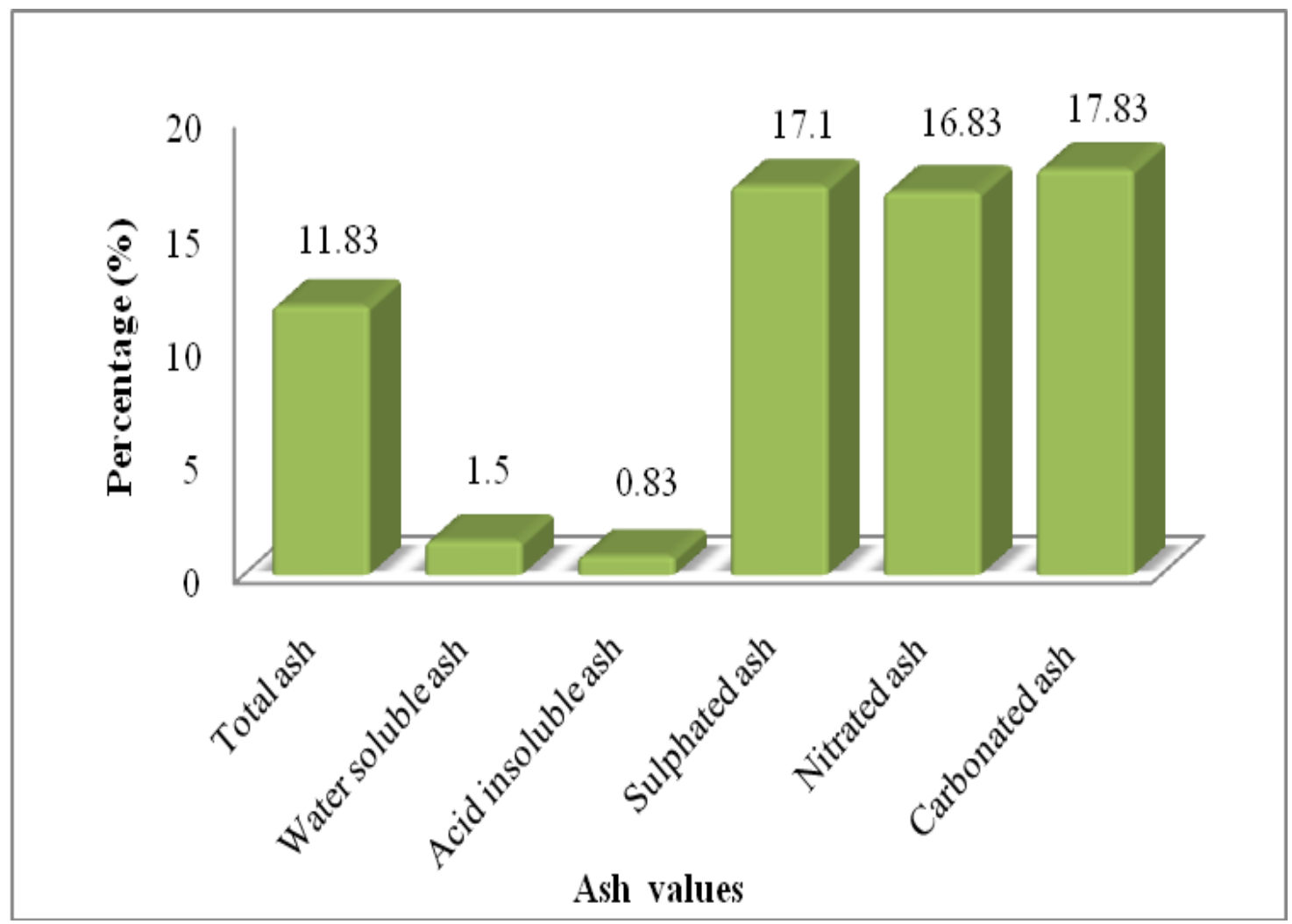

Fig.6 Extractive values of $T$. portulacastrum in different solvents

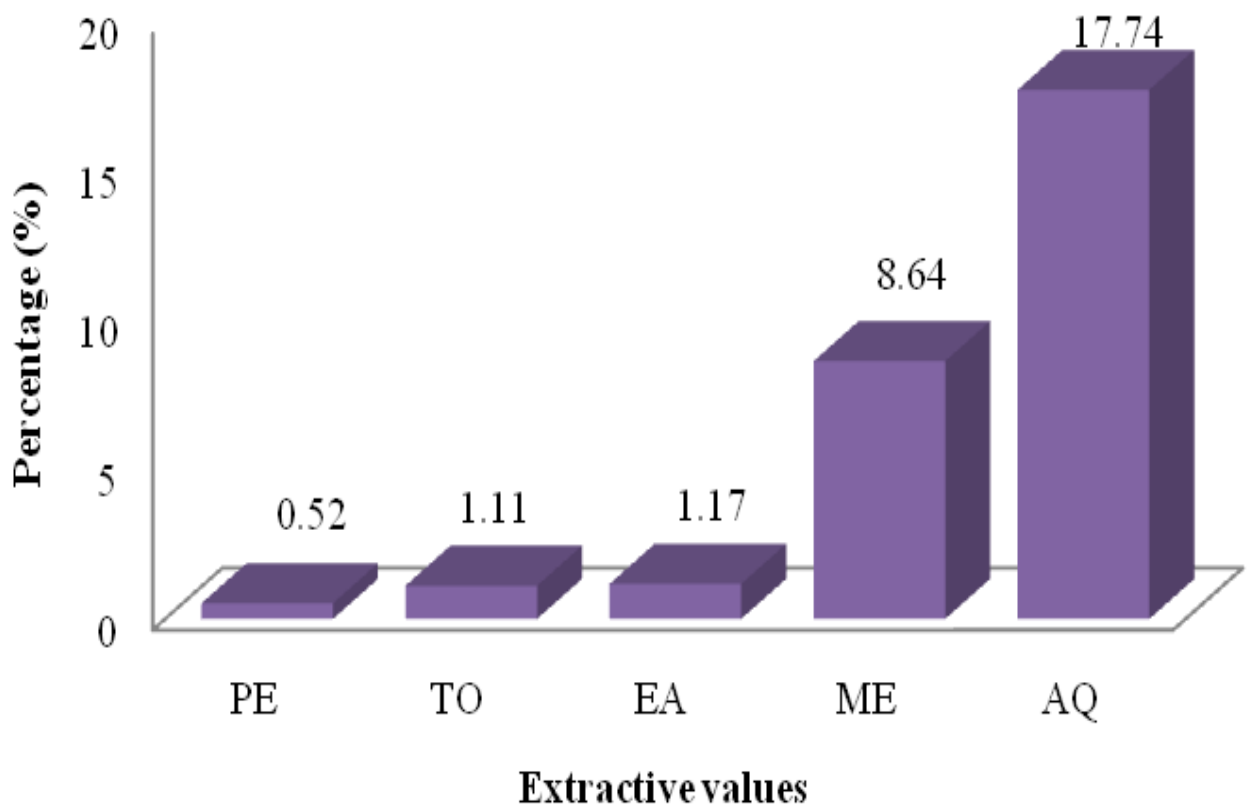


Table.2 Organoleptic features of $T$. portulacastrum

\begin{tabular}{|l|l|l|}
\hline \multicolumn{1}{|c|}{ Characters } & \multicolumn{2}{c|}{ Observation } \\
\hline Part & Leaves & Stem \\
\hline Arrangement & Opposite & - \\
\hline Size & $5-6 \mathrm{~cm}$ length and $2-4 \mathrm{~cm}$ wide & $10 \mathrm{~cm}$ long and $0.2-0.5 \mathrm{~cm}$ thick \\
\hline Shape & Obovate & - \\
\hline Color & Green & Light pink \\
\hline Odour & Characteristic & Characteristic \\
\hline Taste & Bitter & Bitter \\
\hline Appearance & Sub fleshy & Woody \\
\hline Margin & Entire & - \\
\hline Apex & Apicular & - \\
\hline Base & Cunate & - \\
\hline Petiole & Long & - \\
\hline Texture & Glabrous & Glabrous \\
\hline Veination & Reticulate & - \\
\hline Outer surface & Smooth and fleshy & Light pink colour and glabrous surface \\
\hline & & \\
\hline
\end{tabular}

Table.3 Qualitative phytochemical analysis of $T$. portulacastrum plant

\begin{tabular}{|c|c|c|c|c|c|c|c|}
\hline \multirow{3}{*}{$\begin{array}{l}\text { Sr. } \\
\text { No }\end{array}$} & \multirow[t]{3}{*}{ Phytochemicals } & \multicolumn{6}{|c|}{ Whole plant } \\
\hline & & \multirow{2}{*}{$\begin{array}{c}\text { Crude } \\
\text { powder }\end{array}$} & \multicolumn{5}{|c|}{ Different solvent extracts } \\
\hline & & & PE & TO & EA & ME & $\mathbf{A Q}$ \\
\hline \multirow[t]{4}{*}{1} & Alkaloids & & & & & & \\
\hline & (1)Mayer's reagent & - & - & - & - & - & - \\
\hline & (2)Dragondroff's reagent & + & - & - & - & - & ++ \\
\hline & (3)Wagner's reagent & - & + & + & - & ++ & - \\
\hline 2 & Flavonoids & + & - & + & + & + & + \\
\hline 3 & Tannins & + & - & - & - & ++ & - \\
\hline 4 & Phlobatanins & - & - & - & - & - & - \\
\hline 5 & Saponins & ++ & + & + & + & - & ++ \\
\hline 6 & Steroids & + & ++ & +++ & +++ & ++ & - \\
\hline 7 & Cardiac glycosides & + & - & - & - & - & - \\
\hline 8 & Triterpenes & + & - & - & + & ++ & - \\
\hline 9 & Anthocyanins & + & - & - & - & - & - \\
\hline 10 & Phenols & + & - & - & - & - & - \\
\hline 11 & Coumarins & +++ & + & ++ & ++ & + & - \\
\hline 12 & Leucoanthocyanins & ++ & - & - & - & - & - \\
\hline 13 & Quinones & + & - & - & - & - & - \\
\hline
\end{tabular}


Table.4 Fluorescence analysis of $T$. portulacastrum

\begin{tabular}{|c|c|c|c|c|}
\hline $\begin{array}{l}\text { Sr } \\
\text { No. }\end{array}$ & Treatement & Visible light & $\begin{array}{l}\text { Under UV light } \\
\text { short wave } \\
\text { length }(254 \mathrm{~nm})\end{array}$ & $\begin{array}{l}\text { Under UV light } \\
\text { long wave } \\
\text { length }(365 \mathrm{~nm})\end{array}$ \\
\hline 1 & 1 N NaOH(aq) & Green & Black & Black \\
\hline 2 & 1 N NaOH(alco) & Green & Black & Dark green \\
\hline 3 & Ammonia & Dark green & Black & Dark green \\
\hline 4 & Petroleum ether & Yellow & Green & Dark green \\
\hline 5 & $50 \% \mathrm{HCl}$ & Dark green & Black & Dark green \\
\hline 6 & $50 \% \mathrm{H}_{2} \mathrm{SO}_{4}$ & Dark green & Black & Brown \\
\hline 7 & Ethyl acetate & Dark green & Black & Light yellow \\
\hline 8 & Ethyl alcohol & Dark green & Black & Brown \\
\hline 9 & Methanol & Dark green & Black & Brown \\
\hline 10 & $50 \%$ КОН & Brown & Black & Dark green \\
\hline 11 & $50 \% \mathrm{HNO}_{3}$ & Brown & Black & Black \\
\hline 12 & Acetic acid & Dark green & Black & Brown \\
\hline 13 & Iodine in water $(1 \%)$ & Yellowish green & Black & Creamish brown \\
\hline 14 & $\mathrm{FeCl3}$ & Blackish green & Black & Light black \\
\hline
\end{tabular}

The total ash in whole plant powder was $11.83 \%$, while water soluble ash and acid insoluble ash was 1.5 and $0.83 \%$ respectively. The sulphated ash of whole plant powder was $17.1 \%$.

The nitrated ash of whole plant powder was $16.83 \%$. The carbonated ash of whole plant powder was $17.83 \%$. The extractive value of whole plant powder is given in Figure 6. The maximum soluble extractive value was found in methanol (8.64\%). Minimum soluble extractive value was found in petroleum ether $(0.52 \%)$. The water soluble extractive value was $17.74 \%$.

\section{Phytochemical analysis}

The qualitative phytochemical screening of the crude powder of $T$. portulacastrum plant is given in Table 4. In the crude powder of whole plant, coumarins were present in maximum amount followed by saponins and leucoanthocyanins (Table 4). Alkaloids, flavonoids, tannins, steroids cardiac glycosides, triterpenes, anthocyanins, phenols, quinones were present in trace amount while phlobatanins were absent.

The qualitative phytochemical analysis of the plant $T$. portulacastrum in different solvent extracts is given in Table 4. In PE solvent extract, steroids were present in moderate amount; alkaloids, saponins and coumarins were present in trace amount while remaining phytoconstituents were absent (Table 4). In TO solvent extract, steroids were present in maximum amount followed by coumarins; alkaloids and flavonoids were present in trace amount while remaining phytoconstituents were absent. In EA solvent extract, steroids were present in maximum amount followed by coumarins; flavonoids and triterpenes were present in trace amount while remaining phytoconstituents were absent. In ME solvent extract, alkaloids, tannins, steroids and triterpenes were present in moderate amount; flavonids and coumarins were present in trace amount while remaining phytoconstituents were absent. In AQ solvent extract, alkaloids 
and saponins were present in moderate amount; flavonoids were present in trace amount while remaining phytoconstituents were absent.

Pharmacognostical, physicochemical and phytochemical studies are important because once the plant is dried and powdered, it loses its morphological identity and is easily prone to adulteration. Pharmacognostic studies ensures plant identity, lays down standardization parameters which prevent the drug from adulterations. Such study helps in authentication of the plants and ensures reproducible quality of herbal products, which lead to safety and efficacy of natural products (Chanda, 2014; Singh et al., 2017) Standardization is a system to ensure that every packet of medicine that is sold has the correct amount and will induce its therapeutic effect. For the useful application of the plant parts in modern medicine, physico-chemical and phytochemical standardization is also very important (Saxena et al., 2012).

Organoleptic and macroscopic evaluation is a qualitative evaluation based on the study of morphological profile of the plant. The macroscopic evaluation of $T$. portulacastrum showed that the plant was green in colour, shape of leaves was obovae, apex was apicular and base was asymmetrical. The stem was light pink in colour and woody. The microscopic evaluation showed leaf lamina was dorsiventral, unicellular or multicellular trichomes were present. Vascular bundles were conjoint, collateral, close type. Stem showed single layered epidermis, cortex region, secondary growth of vascular bundles, with conjoint, collateral, close, arranged in ring form. The powder study showed unicellular trichomes, spiral vessels, annual vessels, bordered pitted vessels, pitted vessels, paracytic stomata, sclerenchymatous cells, etc. Such studies are reported for other plants like Eucalyptus globules leaf (Shah et al., 2012) and Madhuca indica leaf (Moteriya et al., 2015).

The physicochemical parameters like loss on drying, total ash, acid insoluble ash, water soluble ash, carbonate, nitrated and sulphated ash were determined. The values were in accordance to those reported earlier (Joshi, 2011). Loss on drying was 9.5\%. This indicates that drying process was efficient. Loss on drying for Chaetomorpha antennina was 7\% (Dhanki et al., 2018), for Cinnamomum verum leaf, it was $8.2 \%$ (Kumar et al., 2012) and $8.8 \%$ for Garcinia indica fruit rind (Prasad et al., 2012). This is an important parameter since it indicates the stability of the drug during storage time (Mukherjee, 2002). If the drying process is not efficient, i.e. high moisture content will encourage the growth of microorganism which may lead to the degradation of phytoconstituents of the drug during storage (Evans, 2005). The ash values ranged from $0.83 \%$ to $11.83 \%$. Total ash value was $11.83 \%$ while acid insoluble ash was $0.83 \%$. These values indicate the amount of organic and inorganic material present in the plant sample. The acid insoluble ash normally contains silica and earthy material and indicates contamination. In the present work, it was very negligible hence it can be stated that the plant material is free from contamination. The total ash values are in accordance with those reported for other plants. For e.g. the total ash value was $14 \%$ for root of Cryptolepis sanguinolenta (Odoh and Akwuaka, 2012); 11\% for stem bark of Ficus benghalensis (Semwal et al., 2013) and $17 \%$ for Cassytha filiformis aerial parts (Ambi et al., 2017).

Extractive values give an idea about the chemical constituents of crude drugs and also help in estimation of definite constituents soluble in a particular solvent. The extractive values of organic solvents of $T$. 
portulacastrum ranged from $0.52 \%$ to $8.64 \%$ and water soluble extractive value was $17.74 \%$. This suggests the present of more polar compounds than non-polar compounds. Similar results are reported for other plants. Water soluble extractive value was $20.8 \%$ for Celosia argentia aerial parts (Ghorpade et al., 2012); $18.23 \%$ for Manilkara zapota (Nagani et al., 2012). The extractive value was minimum in petroleum ether (0.52); as also reported for Cordia dichotoma leaf $(0.6 \%)$ (Rahman and Hussain, 2015); Terminalia bellerica leaf (0.9\%) (Menpara et al., 2014) and Ventilago calyculata bark (2\%) (Kumar et al., 2015).

The qualitative phytochemical analysis was done in crude powder and various solvent extracts of the plant. The crude powder of $T$. portulacastrum was rich in coumarins; while its solvent extracts TO and EA were rich in steroids. The plants are endowed with various secondary metabolites that exert particular physiological effect. The preliminary screening will give an idea about the chemical nature of the drug and hence an idea about its therapeutic efficacy. Phytochemical analysis for various solvent extracts of Strychnos potatorum leaves is reported by Kagithoju et al., (2013) and Thespesia populnea root by Patil et al., (2012). The information obtained through such studies will be helpful in further studies of the plant under investigation.

The fluorescence analysis is a simple, rapid pharmacognostic procedure, which is useful in the identification of authenticity of crude drugs and recognizes adulterants. In the fluorescence analysis, the plant parts or crude drugs are examined as such or in their powdered form with a number of various polar and non-polar reagents. It is a valuable analytical tool in the identification of plant samples and crude drugs (Denston, 1946). The fluorescence analysis of $T$. portulacastrum displayed an array of colours that could be employed for identification of probable classes of compounds in the plant. Fluorescence is the phenomenon exhibited by various chemical constituents present in the plant material in the visible range in day light. The ultraviolet light produces fluorescence in many natural products (e.g. alkaloids like berberine) which do not visibly fluoresce in daylight. Some of the substances may be often converted into fluorescent derivatives by using different chemical reagents though they are not fluorescent, hence we can often assess qualitatively some crude drugs using fluorescence as it is the most important parameter of pharmacognostical evaluation (Ansari, 2006; Gupta et al., 2006). Fluorescence analysis is reported for other plants like Bombax ceiba (Wahab et al., 2012), Terminalia arjuna, (Desai and Chanda, 2014) and Cyathula prostrate (Sonibare and Olatubosun, 2015).

Pharmacognostic studies are not part specific. All parts of the plant are important and show therapeutic efficacy, though their efficacy varies. Hence pharmacognostic studies should be done for the part of the plant which is under investigation. Some of the examples of pharmacognostic studies of different parts reported in the literature are root (Shah et al., 2011); rhizome (Jha et al., 2012); stem (Nagani et al., 2011); leaf stem and root of Ageratum conyzoides and Asparagus officinalis (Janarthanan et al., 2016; Begum et al., 2017); leaf (Rakholiya and Chanda, 2012); Aerial parts of Achyranthes aspera (Shukla et al., 2018); flower (Baravalia et al., 2012), Pseudobulbs of Coelogyne cristata (Pramanick, 2016); seed (Pande et al., 2018).

The organoleptic, macroscopic, microscopic characters, phytochemical, physicochemical, fluorescence studies results of this study could be used for the quality control of the crude drug. They will also help to maintain the efficacy and identity of the drug and will 
prevent mishandling of the drug. These parameters can be used as reference standards of this plant and also help in preparation of a monograph.

\section{Acknowledgement}

The authors thank Department of Biosciences (UGC-CAS) for providing excellent research facilities.

\section{References}

Ambi AA, Nuru GF, Mora AT, Ahmad A (2017). Pharmacognostic studies and elemental analysis of Cassytha filiformis Linn. Journal of Pharmacognosy and Phytotherapy. 9(8): 131-137.

Ansari SH (2006). Essentials of Pharmacognosy. Birla Publications Pvt. Ltd. 1st edition. New Delhi.

Balamurugan G, Jagan Mohan CM, Muthusamy P (2009). Protective effect of Trianthema portulacastrum Linn leaves on gentamicin induced nephrotoxicity in rats. Journal of Natural Remedies. 9(2): 165 169.

Baravalia Y, Nagani K, Chanda S (2011). Evaluation of pharmacognostic and physicochemical parameters of Woodfordia fruticosa Kurz. Flowers. Pharmacognosy Journal. 2: 13-18.

Begum A, Sindhu K, Giri K, Umera F, Gauthami G, Vinod Kumar J, Naveen N, Rao KNV, Ali SS. Sri K, Dutt R (2017). Pharmacognostical and Physio-chemical evaluation of Indian Asparagus officinalis Linn family Limiaceae. International Journal of Pharmacognosy and Phytochemical Research. 9(3): 327-336.

Chanda S (2014). Importance of pharmacognostic study of medicinal plants: An overview. Journal of Pharmacognosy and Phytochemistry. 2(5): 69-73.

Chase CR and Pratt R (1949). Fluorescence of powdered vegetable drugs with particular references to development of system of identification. Journal of the American Pharmacists Association. 38(6): 324-331.

Denston TC (1946). A Textbook of Pharmacognosy, Sir Isaac Pitman and Sons, Ltd., London. pp 46-51.

Desai D and Chanda S (2014). Pharmacognostic study and physicochemical analysis of leaves of Terminalia arjuna. Pharmacognosy Journal. 6(6): 15-19.

Dhanki A, Pande J, Donga S, Chanda S (2018). Pharmacognostic standardization of Chaetomorpha antennina and Ulva lactuca, green seaweeds from Gujarat coast. Journal of Pharmacognosy and Phytochemistry (In Press).

Evans WC (2005) Trease and Evans' Pharmacognosy (Edn15th) Rajkamal Electric press, Delhi, India. pp. 516 - 536.

Ghorpade P, Siddiqui A, Patil MJ, Rub RA (2012). Pharmacognostic and phytochemical evaluation of Celosia argentea. Pharmacognosy Journal. 4(33):7-15.

Gupta MK, Sharma PK, Ansari SH, Lagarkha R (2006). Pharmacognostical evaluation of Grewia asiatica fruits. International Journal of Plant Science. 1(2): 249-251.

Harborne AJ (1998). Phytochemical methods a guide to modern techniques of plant analysis. Springer Science and Business Media.

Janarthanan L, Karthikeyan V, Jaykar B, Balakrishnan BR, Senthilkumar KL, Anandharaj G (2016). Pharmacognostic studies on the whole plants of Ageratum conyzoides Linn. (Asteraceae). European Journal of Pharmaceutical and Medical Research. 3(5): 618-626.

Jayasri MA, Gunasekaran, S, Radha A, Mathew TL (2008). Anti-diabetic effect of Costus pictus leaves in normal and streptozotocin-induced diabetic rats. International Journal of Diabetes and Metabolism. 16(3): 117-122.

Jha SV, Bhagwat AM, Pandita NS (2012). Pharmacognostic and phytochemical studies on the rhizome of Nardostachys jatamansi DC. using different extracts. Pharmacognosy Journal. 4(13): 16-22. 
Joshi AJ (2011). Monograph on Indian halophytes. Ocean and Atmospheric Science and Technology Cell, Supported by Ministry of Earth Science New Delhi.

Kadam MP, Yadav KN, Patel AN, Navsare VS, Bhilwade SK, Patil MJ (2012). Phytopharmacopoeial specifications of Garcinia indica fruit rinds. Pharmacognosy Journal. 4(31): 23-28.

Kagithoju S, Godishala V, Pamulaparthi A, Marka R, Nanna RS (2013). Pharmacognostic and phytochemical investigations in Strychnos potatorum Linn. F. Journal of Pharmacognosy and Phytochemistry. 2(4): 46-51.

Khandelwal KR (2008). Practical Pharmacognosy. 19th edn. Pune, India: Nirali Prakashan. pp 49-70.

Kirtikar KR and Basu BD (1933). Indian Medicinal Plants. (Basu LM ed.), 2nd ed., Vol. 2. Allahabad, India. pp 1180-1181.

Kumar G, Banu GS, Pappa PV, Sundararajan M, Pandian MR (2004). Hepatoprotective activity of Trianthema portulacastrum $\mathrm{L}$. against paracetamol and thioacetamide intoxication in albino rats. Journal of Ethnopharmacology. 92:37-40.

Kumar KN, Sangeetha B, Rajalekshmi M, Ravishankar B, Muralidhar R, Yashovarma B (2012). Chemoprofile of tvakpatra; leaves of Cinnamomum verum JS Presl. Pharmacognosy Journal. 4(34):26-30.

Kumar S, Natarajan B, Kanakamma LP, Ashish TF, Pawar RS (2015). Pharmacognostical and phytochemical evaluation of Ventilago calyculata Tul. (Bark). Pharmacognosy Journal. 7(5): 271-275.

Maroo J, Vasu VT, Gupta S (2003). Dose dependent hypoglycemic effect of aqueous extract of Enicostemma littorale blume in alloxan induced diabetic rats. Phytomedicine: International Journal of Phytotherapy and Phytopharmacology. 10(2-3): 196-199.

Menpara D, Desai D, Chanda S (2014). Pharmacognostic, phytochemcial, physicochemical and fluorescence analysis of Terminalia bellerica leaf and stem. World Journal of Pharmaceutical Sciences. 2(4): 390-396.

Moteriya P, Padalia H, Rathod T and Desai D and Chanda S (2015). Pharmacognostic standardization of Madhuca indica leaf and stem, an important medicinal plant. International Journal of Pharmaceutical Sciences and Research. 6(2): 705-711.

Mukherjee PK (2002). Quality control of herbal drugs: an approach to evaluation of botanicals. Business Horizons.

Nagani K, Kaneria M and Chanda S (2012). Pharmacognostic studies on the leaves of Manilkara zapota L. (Sapotaceae). Pharmacognosy Journal. 4(27): 38-41.

Nagani KV, Kevalia J and Chanda S (2011). Pharmacognostical and phytochemical evaluation of stem of Cissus quadrangularis L. International Journal of Pharmaceutical Science and Research. 2(11): 2856-2862.

Odoh UE and Akwuaka CI (2012). Pharmacognostic profile of root of Cryptolepis sanguinolenta (lindl.) Schlechter. Pharmacognosy Journal. 4(28): 40-54.

Pande J and Chanda S (2017). Phyto-PhysicoPharmacognostic study of few medicinal plants of Gujarat. LAP LAMBERT Academic Publishing $\mathrm{GmbH} \& \mathrm{Co}$. KG, Heinrich-Bocking-Straße $\quad 6-8, \quad 66121$ Saarbrucken, Germany.

Pande J, Padalia H, Donga S and Chanda S (2018). Development of quality control parameters for the standardization of Aegle marmelos (Roxb) seed. International Journal of Pharmaceutical Science and Research. (In Press).

Patil PS, Venkatanarayanan R, Argade PD, Shinde PR (2012). Assessment of pharmacognostic and phytochemical standards of Thespesia populnea (L.) root. Asian Pacific Journal of Tropical Biomedicine. 2(3): S1212-1216

Pramanick CC (2016). Pharmacognostic studies on the pseudobulb of Coelogyne cristata Lindl. (Orchidaceae)-An epiphytic orchid of ethno-medicinal importance. Journal of 
Pharmacognosy and Phytochemistry. 5(1): 120-123.

Priyashree S, Jha S, Pattanayak SP (2010). A review on Cressa cretica Linn.: A halophytic plant. Pharmacognosy Reviews. 4(8):161-166.

Rahman MA and Hussain A (2015). Phytochemical and analytical evaluation of Cordia dichotoma Linn. leaves. Pharmacognosy Journal. 7: 58-63.

Rakholiya K and Chanda S (2012). Pharmacognostic, physicochemical and phytochemical investigation of Mangifera indica L. var. Kesar leaf. Asian Pacific Journal of Tropical Biomedicine. S680S684.

Saxena N, Shrivastava PN, Saxena RC (2012). Preliminary physico-phytochemical study of stem bark of Alstonia scholaris (1.) R. Br.-a medicinal plant. International Journal of Pharmaceutical Sciences and Research. 3(4): 1071- 1075.

Semwal A, Kumar R, Teotia UV, Singh $R(2013)$. Development of quality control parameters for the standardization of bark of Ficus benghalensis Linn. Journal of Acute Disease. 2(4): 296-299.

Shah G, Kaur M, Singh PS, Rahar S, Dhabliya F, Arya Y, Shri R (2012). Pharmacognostic parameters of Eucalyptus globulus leaves. Pharmacognosy Journal. 4(34): 38-43.

Shah Rajal, Shah Rumit and Chanda S (2011). Pharmacognostical and preliminary phytochemical investigation of Tephrosia purpurea (Linn.) Pers. root from Gujarat region. International Journal of Pharmaceutical Research. 3 (2): 49-52.
Shastri BN (1952). The Wealth of India- Raw Materials, Vol. 10 CSIR Publications, New Delhi. Pp. 19-23.

Shukla PK, Misra A, Srivastava S (2018). Comparative pharmacognostical and pharmacological evaluation of two Achyranthes species. Pharmacognosy Journal. 10(2): 309-314.

Singh H, Mishra A, Mishra AK (2017). Pharmacognostical and physicochemical analysis of Cleome viscosa L. seeds. Pharmacognosy Journal. 9(3): 372-377.

Sonibare MA and Olatubosun OV (2015). Pharmacognostic and free radical scavenging evaluation of Cyathula prostata (Blume) L. Pharmacognosy Journal. 7(2): 107-116.

Sunder AS, Reddy ARN, Prasad DK, Chander KP, Vemula S (2010). Free radical scavenging activity of methanolic whole plant extract of Trianthema portulacastrum Linn. (Aizoaceae). International Journal of Pharmaceutical Science and Research. 2(2): 589-592.

Tyler V, Brady L, Robber J (1977). Pharmacognosy, Varghese Company, India. pp 103-141.

Wahab S, Hussain A, Ahmad P, Usmani S (2012). Ethanobotanical, pharmacognostical and physico-chemical studies of stem bark of Bombax ceiba L., commonly growing in eastern Uttar Pradesh region of India. Pharmacognosy Journal. 4(32): 55-60.

WHO (1998). Quality control methods for medicinal plants materials. Geneva.

\section{How to cite this article:}

Pande Jyoti, Kanakiya Ankita, Padalia Hemali and Chanda Sumitra. 2018. Physicochemical, Phytochemical and Pharmacognostic Evaluation of a Halophytic Plant, Trianthema portulacastrum L. Int.J.Curr.Microbiol.App.Sci. 7(05): 1486-1502. doi: https://doi.org/10.20546/ijcmas.2018.705.175 